\title{
SPECTRUM OF PROSTATIC LESIONS IN A TERTIARY CARE HOSPITAL- A 51/2-YEAR RETROSPECTIVE DESCRIPTIVE STUDY
}

\author{
Satyasri K1, Sweta Sinha², Kartheek B. V. S
}

${ }^{1}$ Associate Professor, Department of Pathology, RIMS, Srikakulam, Andhra Pradesh, India.

${ }^{2}$ Consultant Pathologist, Department of Pathology, Indus Hospitals, Visakhapatnam, Andhra Pradesh, India.

${ }_{3}^{3}$ Assistant Professor, Department of Pathology, Indus Hospitals, Visakhapatnam, Andhra Pradesh, India.

\section{ABSTRACT}

\section{BACKGROUND}

The incidence of prostatic lesions increases with increasing age. The most important diseases of prostate are inflammatory lesions (prostatitis), nodular hyperplasia (benign prostatic hyperplasia) and carcinoma. Prostatic carcinoma is the second most common cancer in males. Prostatic cancer is usually diagnosed histopathologically based on morphological features like growth pattern, nuclear atypia and absence of basal cells. Establishing or ruling out the diagnosis of carcinoma of prostate has been a challe nging task for pathologists for many years.

\section{MATERIALS AND METHODS}

The present study was a retrospective descriptive study for all the prostatic specimens received between January 2013 and June 2018. The haematoxylin and eosin stained slides were retrieved and reviewed.

\section{RESULTS}

The present study constituted a total of 321 cases with age ranging from 30 years - 85 years. All prostatic specimens were broadly classified into non-neoplastic and neoplastic lesions. The present study included 321 prostatic specimens which comprised of 02 prostatic biopsies, 318 Transurethral Resection of Prostate (TURP) chips and 01 prostatectomy specimens. Out of total 321 cases, non-neoplastic were 279 cases (86.91\%) and neoplastic were 42 (13.09\%) cases. Most common non-neoplastic lesion was nodular hyperplasia 278 cases, of which 117 cases were affected by prostatitis. Out of total nodular hyperplasia with prostatitis, 05 cases were showing granulomas and 112 cases were showing prostatitis (non-granulomatous). In the present study, neoplastic lesions were 42 cases, out of which low-grade Prostatic Intraepithelial Neoplasia (PIN) were 15 cases (37.7\%), adenocarcinoma 25 cases (59.5\%) and other neoplasms 02 cases (4.7\%).

\section{CONCLUSION}

Our study concluded that Benign Prostatic Hyperplasia (BPH) is the commonest lesion among males with features of prostatism and most common type of inflammation associated with BPH is chronic inflammation. The commonest age group affected by both carcinoma and BPH is the seventh decade.

\section{KEY WORDS}

Prostate, Benign Prostatic Hyperplasia, Adenocarcinoma.

HOW TO CITE THIS ARTICLE: Satyasri K, Sinha S, Kartheek BVS. Spectrum of prostatic lesions in a tertiary care hospital- a 51/2year retrospective descriptive study. J. Evolution Med. Dent. Sci. 2018;7(36):3991-3995, DOI: 10.14260/jemds/2018/891

\section{BACKGROUND}

Prostate is one of the most commonly affected organs in males. ${ }^{1}$ The incidence of prostatic lesions increases with increasing age.2,3 The most important diseases of prostate are inflammatory lesions (Prostatitis), nodular hyperplasia (Benign prostatic hyperplasia) and carcinoma. ${ }^{1,2,4}$ Prostatic carcinoma is the second most common cancer and the sixth leading cause of cancer deaths in males. 3,5 Prostatic cancer is usually diagnosed histopathologically based on morphological features like growth pattern, nuclear atypia and absence of basal cells.

Various work had been done by many authors on prostate in the last two decades. This had led to broadening of

'Financial or Other Competing Interest': None.

Submission 22-07-2018, Peer Review 19-08-2018,

Acceptance 25-08-2018, Published 03-09-2018.

Corresponding Author:

Dr. Sweta Sinha,

Consultant Pathologist

Indus Hospitals, Visakhapatnam-530002,

Andhra Pradesh, India.

E-mail: swetadr@rediffmail.com

DOI: $10.14260 /$ jemds $/ 2018 / 891$ histological spectrum of benign prostatic hyperplasia and it has considerably expanded our knowledge about pathology of prostatic adenocarcinoma, special histological variants and most importantly about possible precursor lesions and prognostic factors. ${ }^{6}$

For many years to establish or to rule out the diagnosis of carcinoma of prostate has been a challenging task for pathologists. This problem is even greater in recent times because of advanced medical technology, increased awareness of disease, number of biopsies and less prevalence of carcinoma or questionable carcinoma in such samples. ${ }^{6}$

The benefits of aggressive treatment should be assessed against possible morbidity, while treating the patients of prostatic adenocarcinoma as most of the patients are in advanced stage. For this reason, it is mandatory to stage and grade prostatic carcinoma accurately. Histopathological examination of prostate must include the detailed description of whose features which may be present or associated with BPH and which may lead to progression of this disease. ${ }^{7}$ Hence, inclusion of associated features such as presence or absence of prostatitis, presence or absence of granulomas and PIN changes are very crucial in report. 
This study was undertaken to evaluate the complete spectrum of various prostatic lesions in a tertiary care hospital in coastal Andhra Pradesh and to determine the spectrum of pathological lesions in Transurethral Resection of Prostate (TURP), needle core biopsies and prostatic biopsies and to analyse the clinical and microscopic anatomy of the lesions encountered without taking into account findings of laboratory results.

\section{MATERIALS AND METHODS}

The present study was a retrospective descriptive study carried out in a tertiary care hospital in coastal Andhra Pradesh. The materials for the study included histopathology slides and tissue blocks of all the prostatic specimens received between January 2013 and June 2018. The prostatic material included Transurethral Resection of Prostate [TURP] chips (most common), prostatic biopsies and prostatectomy specimen (rare). The relevant clinical history and data were retrieved from the pathology files. The haematoxylin and eosin ( $\mathrm{H}$ and $\mathrm{E}$ ) stained slides were retrieved and the slides were reviewed under various magnifications of light microscope and the various histopathological findings were noted. Fresh sections were taken from tissue blocks in some cases wherever required and were stained with $\mathrm{H}$ and $\mathrm{E}$ stain.

Our study included 321 prostatic specimens, which comprised of 02 prostatic biopsies, 318 TURP chips and 01 prostatectomy specimens.

The various lesions of prostate were noted down. The various morphological types of $\mathrm{BPH}$ were described according to classification given by Franks. The tumours were classified according to WHO classification ${ }^{8}$ and the histological grading of adenocarcinomas was done as per the Gleason's system. Data were then analysed using tables, figures and charts.

\section{RESULTS}

The present study constituted a total of 321 cases with age ranging from 30 years - 85 years. All prostatic specimens were broadly classified into non-neoplastic and neoplastic. Each category was then sub-classified into specific types according to the standard classification systems.

Out of total 321 cases, non-neoplastic were 279 cases $(86.91 \%)$ and neoplastic were $42(13.09 \%)$ cases (Refer Chart 1). The most common age group affected by both nonneoplastic and neoplastic lesions was 61 - 70 years and rare in $\leq 40$ years. Neoplasm of prostate in the present study is more common after 50 years of age (Refer Table 1 and Chart 2).

Most common non-neoplastic lesion was nodular hyperplasia 279 cases, of which 117 cases were affected by prostatitis. Out of total nodular hyperplasia with prostatitis, 05 cases were showing granulomas and 112 cases were nongranulomatous prostatitis (Refer Table 2). Most common form of prostatitis was chronic prostatitis, predominantly composed of lymphocytes.

One case of nodular hyperplasia with tuberculous granulomatous prostatitis was present (Refer Figure 1), while other 04 cases were non-specific granulomatous reaction with nodular hyperplasia. Tuberculous granulomatous prostatitis showed areas of caseating necrosis with granulomas and Langhan's type giant cells. One case presented with nodular hyperplasia with Candida infection and marked eosinophils. One case of 66 years male, suspected to be neoplastic clinically due to high PSA level was diagnosed as non-specific chronic prostatitis on histopathology.

Most common microscopic features seen in nonneoplastic lesions were basal cell hyperplasia, squamous metaplasia, glandular and stromal hyperplasia, clear cell change, cystically dilated glands, Corpora amylacea and ischaemic changes.

In the present study neoplastic lesions were 42 cases, out of which low-grade PIN were 15 cases (37.7\%), adenocarcinoma 25 cases (59.5\%) and other neoplasm 02 cases (4.7\%) were seen (Refer Table 3 ).

Among 02 cases of other neoplasm- poorly differentiated carcinoma/ non-Hodgkin's lymphoma 01 case (Refer Figure 2) and urothelial carcinoma infiltrating the prostatic tissue 01 case was seen.

In the present study, 25 cases of adenocarcinoma were reported. Histological diagnosis of prostatic cancer were done on morphological features such as growth pattern, nuclear atypia and absence of basal cells. They were graded on the basis of WHO Classification of Tumours of prostate 2016.

All the adenocarcinomas were graded on the basis of Gleason score ${ }^{8}$ (Refer Figure 3).

\section{- Pattern 1}

Circumscribed nodule of closely packed uniform glands.

\section{- $\quad$ Pattern 2}

Circumscribed nodule of loosely packed slightly variable glands.

\section{- $\quad$ Pattern 3}

Single glands of variable size and density with an infiltrative pattern, each separated by at least a strand of stroma.

\section{- $\quad$ Pattern 4}

- $\quad$ Ragged infiltration with poorly formed glands or sheets and cords of fused glands.

- Poorly formed glands include small nests of cells with only a rudimentary formed luminal space (almost rosette like).

- Cribriform pattern.

- Glomeruloid bodies are pattern 4 by definition.

- Clear cell hypernephroid is pattern 4 by definition.

\section{- $\quad$ Pattern 5}

Ragged infiltrative single cells, cords or sheets without gland formation, small solid cylinders or any pattern with comedonecrosis.

\section{These Grade Groups are as follows: ${ }^{8}$}

- Grade Group 1: Gleason score $\leq 6$

- Grade Group 2: Gleason score $3+4=7$

- Grade Group 3: Gleason score 4+ $3=7$

- Grade Group 4: Gleason score $4+4=8,3+5=8,5+$ $3=8$

- $\quad$ Grade Group 5: Gleason scores 9 - 10.

Most common Gleason score was 7. Total 13 cases of Gleason score $7(3+4$ and $4+3$ ) were seen (56.52\%). Least Gleason score was $4(2+2)$ seen in 03 cases (and highest Gleason score was $10(5+5)$ seen in 01 case $(4.35 \%)$ (Refer Table 4). Perineural invasion could be identified in 11 cases (47.82\%) (Refer Figures 4, 5 and 6). Figure 4 depicts glands of variable size and density with an infiltrative pattern, each separated by strand of stroma (Pattern 3). 
Figure 5: Depicts prostatic adenocarcinoma showing solid sheets of tumour cells (Pattern 5).

Figure 6: Prostatic adenocarcinoma showing glomeruloid pattern (Pattern 4). Vascular emboli was seen in 01 case (Refer Figure 7).

\begin{tabular}{|c|c|c|c|}
\hline $\begin{array}{c}\text { Age } \\
\text { (Years) }\end{array}$ & $\begin{array}{c}\text { Non-Neoplastic } \\
\text { Lesion, N (\%) }\end{array}$ & $\begin{array}{c}\text { Neoplastic } \\
\text { Lesion, N (\%) }\end{array}$ & Total, N (\%) \\
\hline$\leq 40$ & $01(0.31 \%)$ & 0 & $01(0.31 \%)$ \\
\hline $41-50$ & $11(3.4 \%)$ & 0 & $11(3.4 \%)$ \\
\hline $51-60$ & $94(29.3 \%)$ & $13(4.05 \%)$ & $107(33.35 \%)$ \\
\hline $61-70$ & $104(32.4 \%)$ & $17(5.3 \%)$ & $121(37.7 \%)$ \\
\hline $71-80$ & $62(19.3 \%)$ & $06(1.87 \%)$ & $68(21.17 \%)$ \\
\hline$\geq 81$ & $07(2.2 \%)$ & $06(1.87 \%)$ & $13(4.07 \%)$ \\
\hline Total & $\mathbf{2 7 9}(\mathbf{8 6 . 9 1 \% )}$ & $\mathbf{4 2}(13.09 \%)$ & \\
\hline Table 1. Age Wise Incidence of Prostatic Lesions, Total \\
\hline \multicolumn{4}{|c}{ No. of Cases 321} \\
\hline
\end{tabular}

\begin{tabular}{|c|c|c|c|c|}
\hline \multirow[b]{3}{*}{ 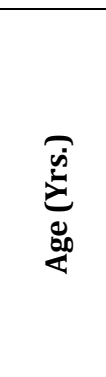 } & \multirow[b]{3}{*}{ 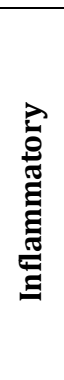 } & \multicolumn{3}{|c|}{ Nodular Hyperplasia } \\
\hline & & \multirow[t]{2}{*}{$\begin{array}{c}\text { Without } \\
\text { Prostatitis }\end{array}$} & \multicolumn{2}{|c|}{$\begin{array}{c}\text { With } \\
\text { Prostatitis }\end{array}$} \\
\hline & & & 之莕 & 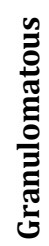 \\
\hline$\leq 40$ & & & 01 & \\
\hline $41-50$ & & 04 & 07 & \\
\hline $51-60$ & & 54 & 39 & 01 \\
\hline $61-70$ & 01 & 62 & 41 & \\
\hline $71-80$ & & 36 & 22 & 04 \\
\hline$\geq 81$ & & 05 & 02 & \\
\hline Total & 01 & 161 & 112 & 05 \\
\hline
\end{tabular}

\begin{tabular}{|c|c|c|c|c|}
\hline \multirow{2}{*}{$\begin{array}{c}\text { Age } \\
\text { (Years) }\end{array}$} & $\begin{array}{c}\text { Low Grade } \\
\text { PIN }\end{array}$ & $\begin{array}{c}\text { High Grade } \\
\text { PIN }\end{array}$ & $\begin{array}{c}\text { Adeno- } \\
\text { carcinoma }\end{array}$ & Others \\
\hline$\leq 30$ & - & - & - & - \\
\hline $30-40$ & - & - & - & - \\
\hline $41-50$ & - & - & - & - \\
\hline $51-60$ & 06 & - & 06 & 01 \\
\hline $61-70$ & 07 & - & 09 & 01 \\
\hline $71-80$ & 01 & - & 05 & - \\
\hline$\geq 81$ & 01 & - & 05 & - \\
\hline Total & 15 & Nil & 25 & 02 \\
\hline Table 3. Age Wise distribution of Neoplastic Lesions, \\
\hline \multicolumn{7}{|c|}{ Total= 42 Cases } \\
\hline
\end{tabular}

\begin{tabular}{|c|c|c|c|c|}
\hline $\begin{array}{c}\text { Gleason } \\
\text { Score }\end{array}$ & $\begin{array}{c}\text { No. of } \\
\text { Cases }\end{array}$ & $\mathbf{\%}$ & $\begin{array}{c}\text { Remark, } \\
\text { if any }\end{array}$ & $\begin{array}{c}\text { WHO Grade } \\
\text { Group }\end{array}$ \\
\hline $4(2+2)$ & 03 & 13.04 & & 1 \\
\hline $5(2+3)$ & 01 & 4.35 & & 1 \\
\hline $6(3+3)$ & 01 & 4.35 & & 1 \\
\hline $7(3+4)$ & 10 & 43.48 & $\begin{array}{c}\text { Perineural invasion } \\
\text { present in all except } \\
\text { 02 cases. }\end{array}$ & 2 \\
\hline $7(4+3)$ & 03 & 13.04 & $\begin{array}{c}\text { Perineural invasion } \\
\text { present in 02 cases. } \\
\text { Vascular emboli } \\
\text { present in 01 case. }\end{array}$ & 3 \\
\hline
\end{tabular}

\begin{tabular}{|c|c|c|l|c|}
\hline $8(4+4)$ & 01 & 4.35 & & 4 \\
\hline $9(4+5)$ & 03 & 13.04 & & 5 \\
\hline $10(5+5)$ & 01 & 4.35 & $\begin{array}{c}\text { Perineural invasion } \\
\text { present }\end{array}$ & 5 \\
\hline Table 4. Different Gleason Scores for Adenocarcinomas, \\
Total= 23 Cases \\
\hline
\end{tabular}

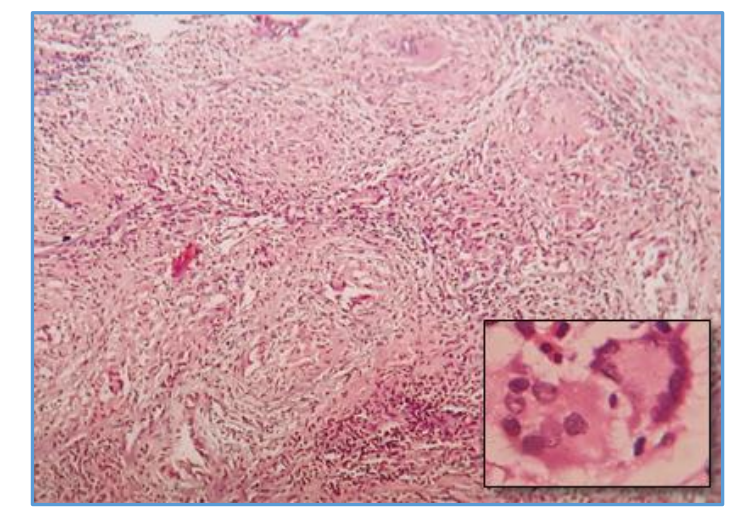

Figure 1. Microphotograph showing Caseating Necrosis, Granulomas with Langhans type of Giant Cells. H and $E$ Stain, 10x, Insat- 40x

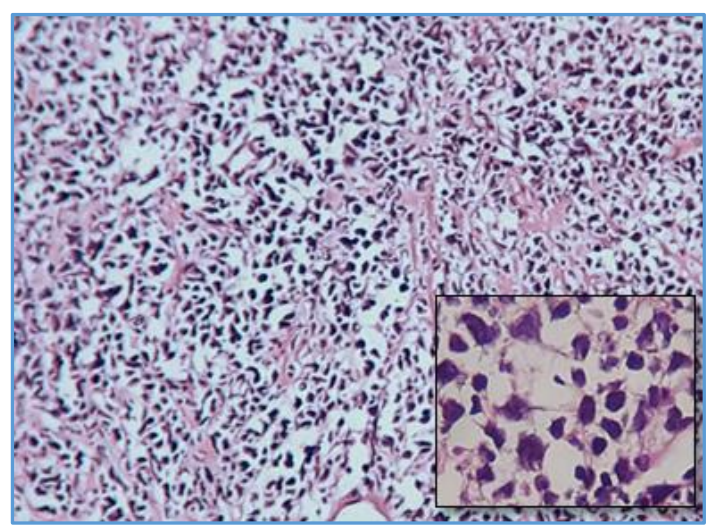

Figure 2. Poorly differentiated Carcinoma/ Non-Hodgkin's Lymphoma. H and E Stain, 10x, Insat- 40x

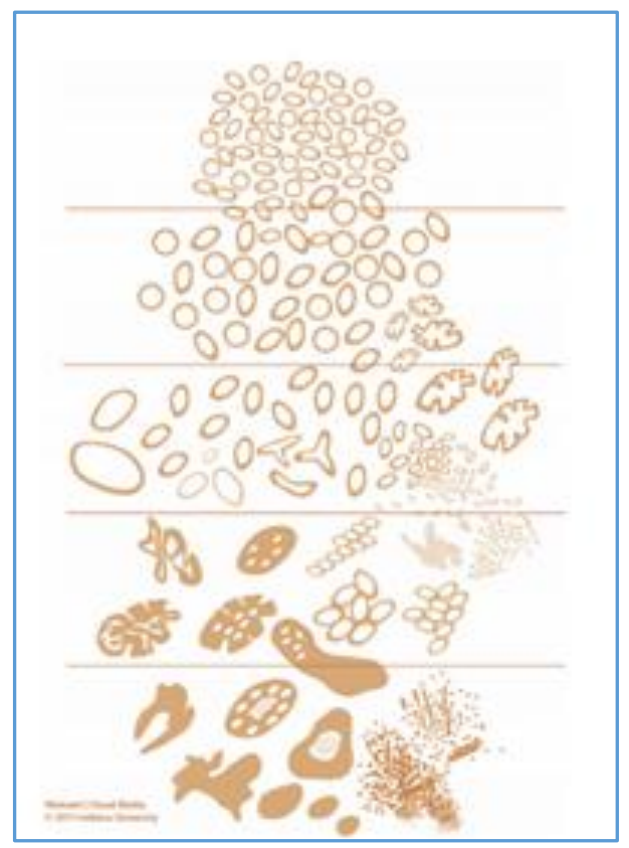

Figure 3. Modified Gleason Grading Schematic Diagram, according to the International Society of Urological Pathology 


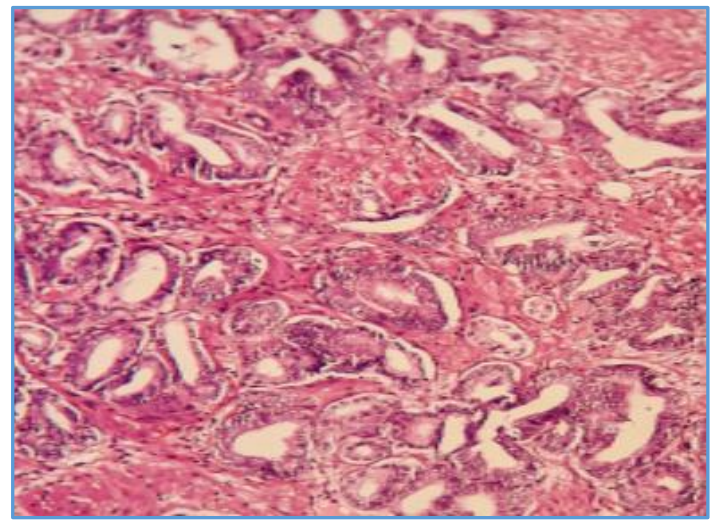

Figure 4. Prostatic Adenocarcinoma showing Anaplastic Glands. H and E, 40X

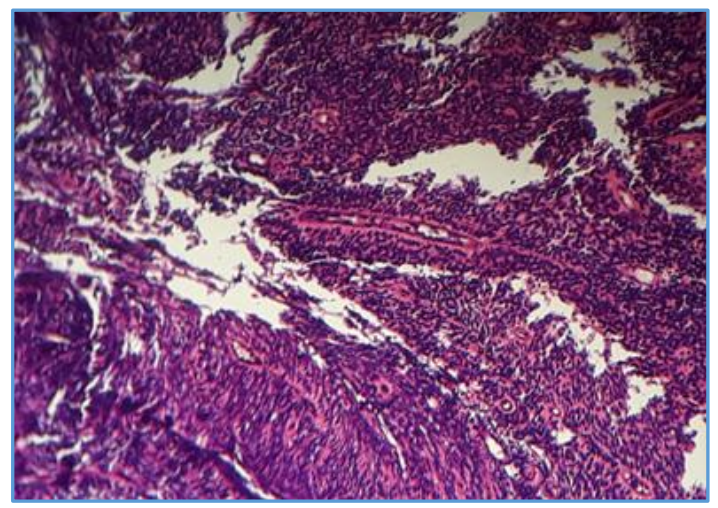

Figure 5. Prostatic Adenocarcinoma showing Solid Sheets of Tumour Cells. Hand E Stain, 10x

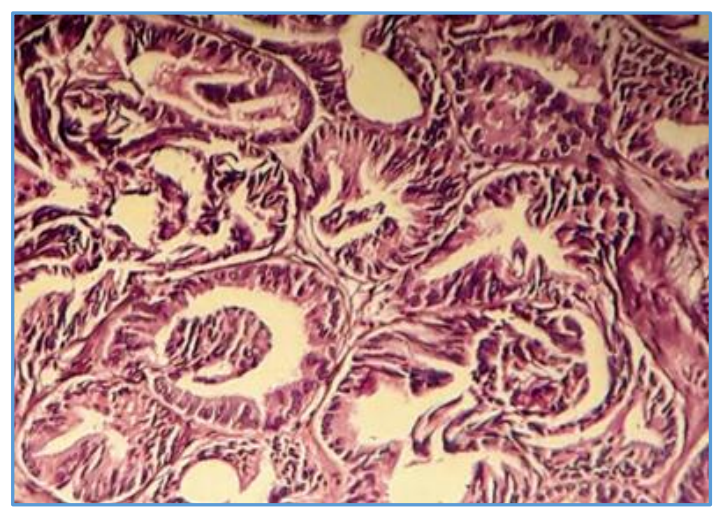

Figure 6. Prostatic Adenocarcinoma showing Glomeruloid Pattern. H and E Stain, 40x

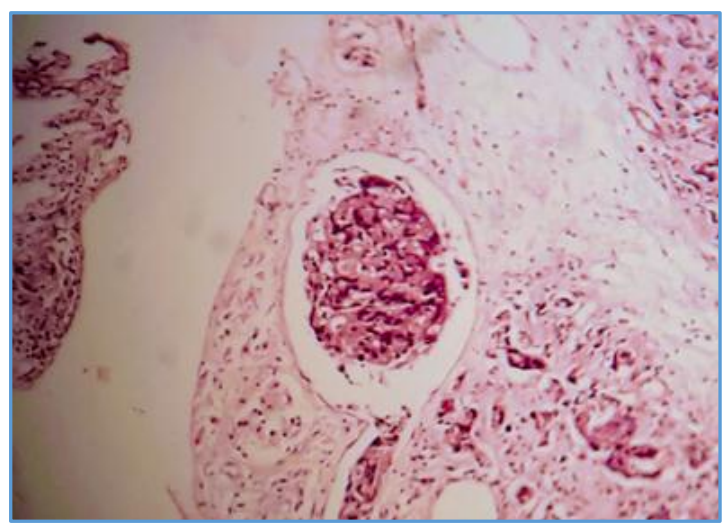

Figure 7. Prostatic Adenocarcinoma showing Vascular Invasion by Tumour Cells. H and E Stain, 40x

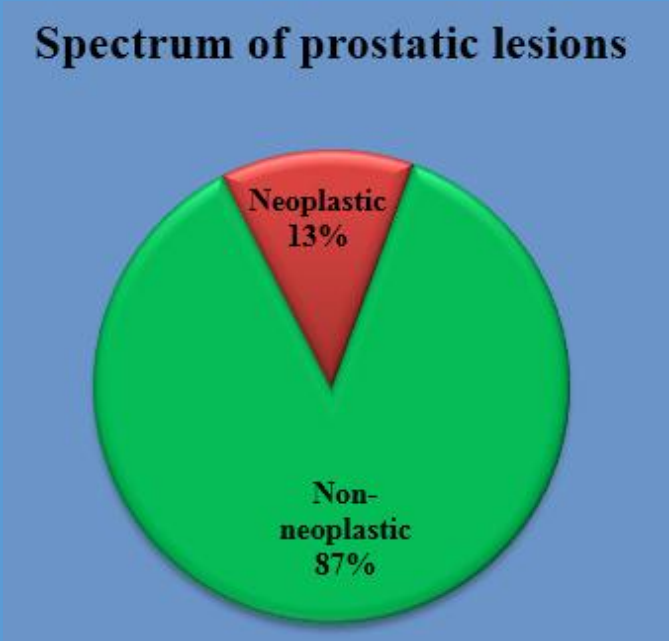

Chart 1. Spectrum of Prostatic Lesions

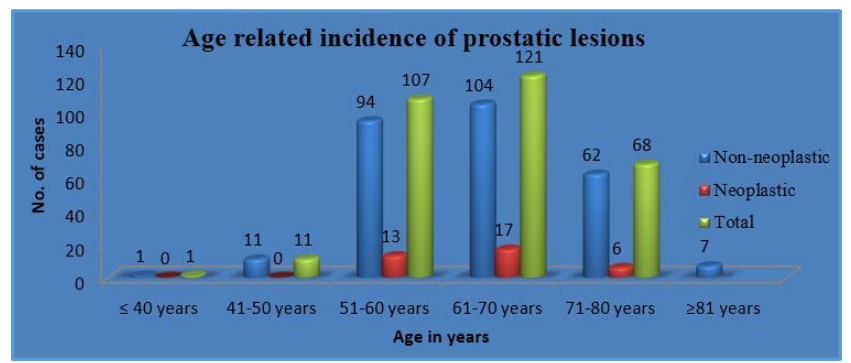

Chart 2. Age Related Incidence of Prostatic Lesions

\section{DISCUSSION}

The prostate is a pear-shaped organ with glands and stroma. It has three major glandular regions- peripheral zone, central zone and transitional zone. Prostatic hyperplastic lesions are common in transition zone, while carcinomas are common in peripheral zone. ${ }^{1}$

The glandular component of the organ is composed of acini and ducts. Both acini and ducts mainly contain secretory cells, basal cells and few neuroendocrine cells. The secretory cells produce Prostatic Acid Phosphatase (PAP) and prostatespecific antigen (PSA) and also coexpress various keratins and vimentin. The basal cells express high molecular weight cytokeratin (e.g. 34ßE12, CK8.12) and p63. These basal cell markers are helpful in making differential diagnosis between well-differentiated carcinomas (basal cells are absent) and benign conditions that mimic it (generally present, although sometimes in a discontinuous fashion). The neuroendocrine cells express chromogranin A and B, secretogranin II, somatostatin, calcitonin and bombesin. ${ }^{9}$

Two most common prostatic lesions, BPH and carcinoma cause enlargement of the prostate gland with urethral constriction and various urinary symptoms.10,11 Benign Prostatic Hyperplasia (BPH) and carcinoma of the prostate are more commonly seen with advancing age.12,13 Most commonly prostatitis may be acute and chronic bacterial prostatitis, chronic abacterial prostatitis and granulomatous prostatitis. The most common form of prostatitis is chronic abacterial prostatitis. Granulomatous prostatitis may be specific or non-specific. ${ }^{14}$

The aim of this study was to evaluate the spectrum of various histological lesions in prostatic specimens. BPH was the most common lesion (86.9\%) as compared to prostatic malignancies $(13.1 \%)$ in the present study, which is 
correlating with the studies done by Sharma A et al (BPH91.02\%), ${ }^{1}$ Bhat et al (BPH- 92.4\%), ${ }^{4}$ Puttuswamy et al (BPH$80.6 \%)^{15}$ The most common age for benign and malignant lesions were $61-70$ yrs. followed by $51-60$ years. Similar age incidence was seen in Hirachand $S$ et al. ${ }^{2}$, Garg et al. ${ }^{5}$ Shirish et al $^{6}$ and Patel et al. ${ }^{11}$ Sharma A et al $^{1}$ observed the most common age as 61 - 70 yrs. followed by $71-80$ years.

Among 279 cases of non-neoplastic lesions BPH was associated with chronic inflammation in 118 cases. Granulomatous prostatitis was seen in 05 cases, of which 01 case was tuberculous, 01 case was associated with Candida infection and 01 case was non-specific granulomatous inflammation.

Among 42 cases of neoplastic lesions, 25 cases of adenocarcinoma, 01 case of poorly differentiated carcinoma/non-Hodgkin's lymphoma and 01 case of urothelial carcinoma infiltrating the prostatic tissue was seen. All PIN lesions were low-grade (25 cases) in the present study. Maximum number of LGPIN cases were in $61-70$ years' age group. This correlates with the study of Sharma A et al. ${ }^{1}$

In the present study, most common Gleason score was 7 . Total 13 cases $(56.52 \%)$ were in Gleason score 07 . Similar findings were seen in study done by Chandanwale Shirish $S$ et al, ${ }^{6}$ where most common Gleason score was 7 in $9(52.94 \%)$ cases and Anushree and Venkatesh ${ }^{13}$ (58.3\%).

Perineural invasion was identified in 11 cases (47.82\%). Study conducted by Garg et $\mathrm{al}^{5}$ also showed $42.5 \%$ of neoplastic lesions with perineural invasion.

\section{CONCLUSION}

Our study concluded that Benign Prostatic Hyperplasia (BPH) is the commonest lesion of prostate with features of prostatism and most common pattern of inflammation associated with BPH is chronic inflammation. The commonest age group affected by both carcinoma and BPH is the seventh decade. Prostatic TURP chips make a good percentage of the surgical pathology workload. As the incidence of BPH is more as compared to neoplastic lesions, thorough screening is mandatory for incidental PIN lesions and malignancies.

\section{REFERENCES}

[1] Sharma A, Sharma M, Gandhi S, et al. Histomorphological spectrum of prostatic lesions: a retrospective analysis of transurethral resection of prostate specimens. Int J Res Med Sci 2017;5(6):23738.
[2] Hirachand S, Dangol UMS, Pradhanang S, et al. Study of prostatic pathology and its correlation with prostate specific antigen level. J Pathol Nepal 2017;7(1):1074-7.

[3] Josephine A. Clinicopathological study of prostatic biopsies. J Clin Diagn Res 2014;8(9):4-6.

[4] Bhat S, Chaudhri S, Bhat P, et al. Histopathological study of prostatic diseases in Garhwal Region. Int J Sci Study 2015;3(8):136-40.

[5] Garg M, Kaur G, Malhotra V, et al. Histopathological spectrum of 364 prostatic specimens including immunohistochemistry with special reference to grey zone lesions. Prostate Int 2013;1(4):146-51.

[6] Shirish C, Jadhav SP, Anwekar CS, et al. Clinicopathological study of benign \& malignant lesions of prostate. IJPBS 2013;3(1):162-78.

[7] Di Silverio F, Gentile V, De Matteis A, et al. Distribution of inflammation, pre-malignant lesions, incidental carcinomas in histologically confirmed benign prostatic hyperplasia: a retrospective analysis. Eur Urol 2003;43(2):164-75.

[8] Humphrey PA, Moch H, Cubilla AL, et al. The 2016 WHO classification of tumours of the urinary system and male genital organs-part B: prostate and bladder tumours. Eur Urol 2016;70(1):106-19.

[9] Rosai J. Male reproductive system. In: Rosai J, ed. Rosai and Ackerman's surgical pathology. 9th edn. St Louis Missouri: Mosby Elsevier 2004;1361-412.

[10] Kohale MG, Kulkarni N, Kulkarni SN, et al. Clinical spectrum of prostatic lesions: a clinicopathological study. MedPulse - Int Med J 2016;3(12):1046-50.

[11] Patel SK, Surti HB. Analysis of prostatic biopsies in a tertiary care hospital in correlation with prostatespecific antigen levels: a clinicopathological study. Int J Med Sci Public Health 2017;6(5):842-46.

[12] Yadav M, Desai H, Goswami H. Study of various histopathological patterns in prostate biopsy. Int J Cur Res Rev 2017;9(21):58-63.

[13] Anushree CN, Venkatesh K. Morphological spectrum of prostate lesions - a clinic pathological study. Med Innov 2012;1:49-54.

[14] Epstein JI, Lotan TL. The lower urinary tract and male genital system. In: Kumar V, Abbas AK, Aster JC, eds. Robbins and Cotran pathologic basis of disease. 9th edn. New Delhi: Elsevier 2014:980-90.

[15] Puttaswamy K, Parthiban R, Shariff S. Histopathological study of prostatic biopsies in men with prostatism. J Med Sci Health 2016;2(1):11-7. 